\title{
Use of double wire traction for removal of pacemaker leads
}

\author{
Christine Arnold ${ }^{a}$, Joanna Tenkorang ${ }^{b}$, Juerg Schlaepfer ${ }^{b}$, Martin Fromer $^{b}$ \\ a Department of Internal Medicine, Centre Hospitalier Universitaire Vaudois, University of Lausanne, Lausanne, Switzerland \\ b Department of Cardiology, Centre Hospitalier Universitaire Vaudois, University of Lausanne, Lausanne, Switzerland
}

\section{Summary}

Retraction of device leads may be a risky procedure. We report a case of a patient with a pacemaker pocket infection and two abandoned leads. Locking stylets were introduced in each electrode and both stylets were pulled through the rotating blade with simultaneous retraction and rotation of the blade. This technique allowed successful liberation of both leads at once.

Key words: pacemaker; lead extraction; pacemaker erosion; pocket infection; endocarditis; pacemaker complication

\section{Case report}

A 74-year-old male patient was referred to our institution for extraction of two old abandoned pacemaker leads with skin necrosis and perforation. He had a dual-chamber pacemaker (Medtronic KAPPA KDR 401) implanted 11 years previously for third degree atrioventricular block. A second ventricular lead was implanted some years later (exact data unknown) because of pacing and sensing failure, so the patient finally had three leads (two ventricular and one auricular). After numerous interventions for recurrent pocket infection and skin extrusion (table 1), the patient was referred to us. The leads had been cut almost at the entry of the subclavian vein. Manual traction was not successful using a locking stylet (Spectranetics LLD EZ). We then tried to liberate each lead separately by using the rotating blade of the mechanical liberator (Cook Evolution 11 French), again without success. Therefore we decided to modify the procedure. As it was suspected that both leads were in one envelope of connective tissue with adherence to the subclavian and

Funding / potential competing interests: Martin Fromer (corresponding author) is active in clinical research and has received educational grants by Medtronic Inc., St. Jude Inc., Boston scientific Inc. superior vena cava wall structures, we decided to pull the two leads together (each secured with a locking stylet) into the bladed inner sheath of the mechanical liberator (fig. 1). In addition, the rotatable bladed sheath was protected by an outer sheath to allow free rotation of the blade. Special care was taken to

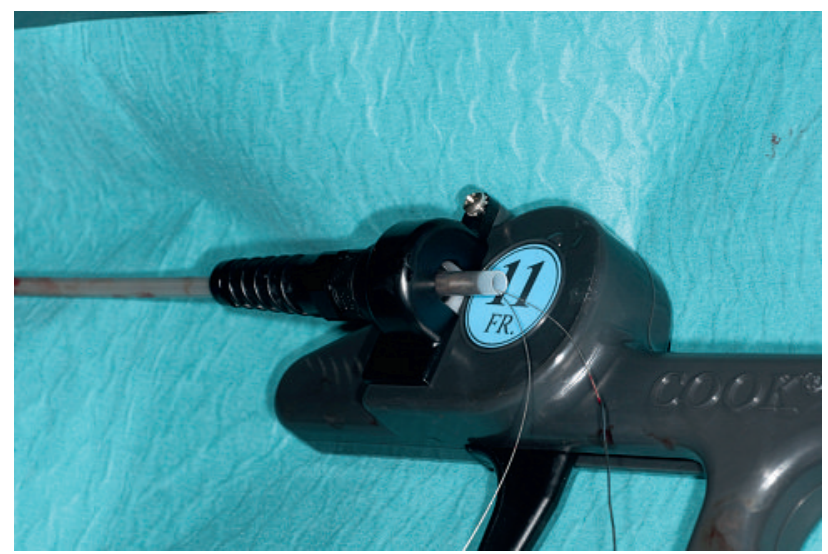

Figure 1

The Cook Evolution 11 French liberator used for the intervention. The two leads, each with a locking stylet, were introduced together into the liberator. An outer sheath was also placed around the liberator to allow free rotation of the bladed sheath. Constant mechanical traction was applied to each locking stylet with the use of the rotating blade of the mechanical dilator and push and pull action on the outer sheath.

stop the liberating manoeuvre once the blade reached the area where the leads separated (fig. 2). By applying simultaneous mechanical traction to each locking stylet and activating the rotating blade with push and pull action on the outer sheath, we finally pulled out both leads simultaneously. Cultures of the lead tips were all positive for a Staphylococcus epidermidis resistant to methicillin.

\section{Discussion}

We propose the described technique, of double retraction by introducing the locking stylet in each electrode and then passing the two stylets in one common rotat-

Correspondence:

Professor Martin Fromer, MD

Department of Cardiology

Centre Hospitalier Universitaire Vaudois

Rue du Bugnon 46

CH-1011 Lausanne

Switzerland

Martin.Fromer@chuv.ch 
ing blade, as an alternative approach in specific cases. By doing so it becomes possible to retract compacted electrodes in a better way than by trying to liberate the electrodes one by one. The more devices that are implanted, the more electrode failures and system infections will be observed. Recently, a $42 \%$ increase in the

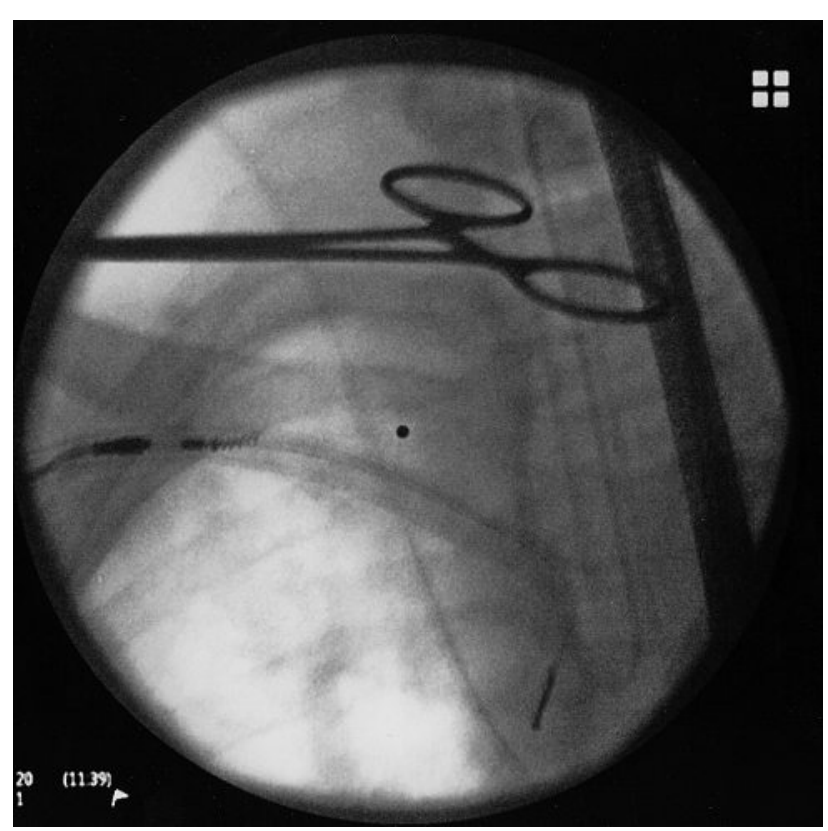

Figure 2

On this fluoroscopy picture, the two leads can be seen together within the mechanical dilatator. Special care was taken to stop the liberating manoeuvre once the blade reached the area where the leads separated. The entire procedure was done under fluoroscopy. implantation rate among Medicare beneficiaries was reported during the years 1990 to 1999. This was associated with a rise in the number of cardiac device infections by $124 \%$ during the same period [1]. In 2000 , the Heart Rhythm Society, formerly called the North American Society for Pacing and Electrophysiology (NASPE), published guideline indications for lead removal [2]. A localised pocket infection was at that time not an absolute indication for system extraction if the lead could be cut through a clean incision completely separated from the infected area. In the revised recommendations by the Heart Rhythm Society this has been moved to a class I indication [3, 4]. Complete device

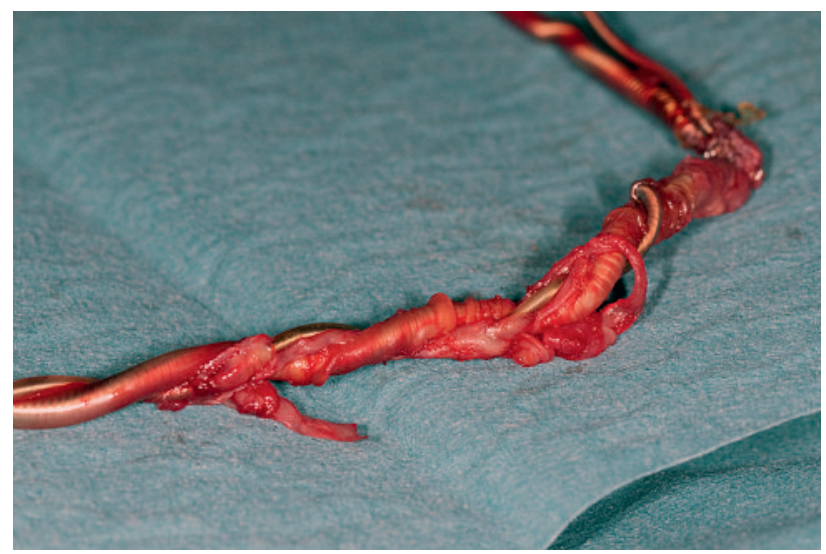

\section{Figure 3}

Compact fibrous connective tissue around atrial and ventricular leads. This can explain the difficulty of pulling out each lead separately, and the success of the subsequent procedure.

Table 1

Case history.

\begin{tabular}{|c|c|c|c|}
\hline Chronology & Diagnosis & Intervention & Medical treatment \\
\hline May 1998 & Third degree AV Block & Dual chamber PM implantation & \\
\hline Some years later & Pacing and sensing failure & Second ventricular lead implantation & \\
\hline December 2005 & Battery end of life & Generator change & \\
\hline October 2007 & $\begin{array}{l}\text { PM skin extrusion and infection } \\
\text { with multiresistant Staph. } \\
\text { epidermidis }\end{array}$ & Generator removal & $\begin{array}{l}\text { Sulfamethoxazole/trimethoprim } \\
\text { and rifampicine per os for } 10 \\
\text { days }\end{array}$ \\
\hline January 2008 & & $\begin{array}{l}\text { New generator implantation (same } \\
\text { pocket) and reconnection with } \\
\text { original leads }\end{array}$ & \\
\hline October 2008 & PM skin extrusion & $\begin{array}{l}\text { Skin debridement and covering by } \\
\text { Limberg transposition flap }\end{array}$ & $\begin{array}{l}\text { Amoxicillin clavulanate IV } \\
\text { followed by moxifloxacine per os } \\
\text { for } 14 \text { days in total }\end{array}$ \\
\hline May 2009 & $\begin{array}{l}\text { PM skin extrusion and infection } \\
\text { with multiresistant Staph. } \\
\text { epidermidis }\end{array}$ & Second generator removal & $\begin{array}{l}\text { Piperacillin/tazobactam IV } \\
\text { followed by clindamycin } \\
\text { for } 4 \text { weeks in total }\end{array}$ \\
\hline August 2009 & Lead (ventricular) extrusion & $\begin{array}{l}\text { Ventricular lead removal; atrial and } \\
\text { second ventricular leads are cut, } \\
\text { buried and covered with silicone tips }\end{array}$ & \\
\hline October 2009 & New lead extrusion & & \\
\hline November 2009 & Referral to our institution & Leads extraction & $\begin{array}{l}\text { Vancomycin IV for } 14 \text { days in } \\
\text { total }\end{array}$ \\
\hline
\end{tabular}


and lead removal is now recommended in all patients with pacemaker pocket infection even without clinically evident involvement of the transvenous portion of the lead system. It has been shown that management with antibiotics and generator pocket debridement without hardware removal has a high failure rate. The history of our patient is a typical example of the failure of medical treatment. In the current case, the two pacing electrodes were massively encased by fibrotic tissue. It is known that there is a correlation between the thickness of the fibrous tissue and the time since implantation [5]. Applying simple traction even with the locking stylet is often ineffective. In our case it seemed impossible without reasonable risk to liberate each lead separately. However, once the two locking stylets were introduced within one rotating blade it became possible to liberate and retract both electrodes within one block (fig. 3). It is not our intention to propose this modification as a standard for the procedure of transvenous lead extraction. We propose it as an alternative method in situations when the classical approach of liberating one electrode after the other is not successful and when the operator suspects that the electrodes are compacted together by dense connective tissue. In this case we even suggest the use of the 13 French mechanical liberator to pass the two electrodes. However with a larger diameter, air aspiration might become a risk that has to be evaluated carefully during the manoeuvre. The risk of major vein laceration with the mechanical dilator has been described and can lead to death [6]. We cannot discuss whether the use of a laser technique would have been superior as it is not part of our standard equipment. We could speculate that the specific properties of the laser might have helped to liberate one lead from the other [7]. However it is an expensive procedure which needs a large amount of oper- ator experience and which we would probably not have used as a first choice. The electrosurgical procedure has been abandoned at our institution. The Heart Rhythm Society expert consensus in transvenous lead extraction does not promote one extraction tool over another. They suggest that having a broad variety of extraction tools and techniques increases the chances of success and limits complications [4]. We performed the procedure in the operating theatre. Experienced cardiothoracic surgical cover with standby extracorporeal circulation is essential when performing these procedures [4]. These guidelines have been respected by our team.

\section{References}

1 Cabell CH, Heidenreich PA, Chu VH, Moore CM, Stryjewski ME, Corey GR, et al. Increasing rates of cardiac device infections among Medicare beneficiaries: 1990-1999. Am Heart J. 2004;147:582-6.

2 Love CJ, Wilkoff BL, Byrd CL, Belott PH, Brinker JA, Fearnot NE, Friedman RA, et al. Recommendations for extraction of chronically implanted transvenous pacing and defibrillator leads: indications, facilities, training. Pacing Clin Electrophysiol. 2000;23:544-51.

3 Lead Extraction 2008: Critical Review and Implementation of HRS Guidelines, HR 2008 satellite symposium co-sponsored by Cleveland Clinic and Heart Rythm Society, Course directors Bruce Wilkoff, Charles Love, Charles Byrd, May 15, 2008. San Francisco, CA.

4 Wilkoff BL, Love CJ, Byrd CL, Bongiorni MG, Carrillo RG, Crossley GH, et al. Transvenous Lead Extraction: Heart Rythm Society Expert Consensus on Facilities, Training, Indications, and Patient Management: This document was endorsed by the American Heart Association (AHA). Heart Rhythm. 2009;6:1058-104.

5 Robboy SJ, Harthorne JW, Leinbach RC, Sanders CA, Austen WG. Autopsy findings with permanent pervenous pacemakers. Circulation. 1969;39:495-501.

6 Hauser RG, Katsiyiannis WT, Gornick CC, Almquist AK, Kallinen LM. Deaths and cardiovascular injuries due to device-assisted implantable cardioverter-defibrillator and pacemaker lead extraction. Europace. 2010;12(3):395-401.

7 Maytin M, Epstein LM. The challenges of transvenous lead extraction. Heart. 2011;97:425-34. 